\title{
HMGB2 wt Allele
}

National Cancer Institute

\section{Source}

National Cancer Institute. HMGB2 wt Allele. NCI Thesaurus. Code C52077.

Human HMGB2 wild-type allele is located within $4 \mathrm{q} 31$ and is approximately $3 \mathrm{~kb}$ in length.

This allele, which encodes high mobility group protein B2, plays a role in the replication, repair and recombination of DNA. 